Resenhas

\title{
Um olhar sobre os 'olhares'
}

\section{Entre o amor e a palavra: olhares sobre Arriéte Vilela}

BRANDÃO, lzabel (Org.).

Maceió: Edições Catavento, 2001. 204 p.

A literatura, como toda forma de arte, inspira, expira, transpira, pensa e re-presenta as diversas realidades políticas, sociais e históricas no seio das quais é produzida.

Neste momento, cabe perguntarmos: qual o status da literatura em uma época em que o pensamento teórico tem se caracterizado pelo questionamento de suas próprias certezas e referências? Como fica a relação entre 'autor/a' e obra; 'autor/a' e 'realidade' diante do dilema teórico acerca da legitimidade do sujeito humanista, conhecedor e organizador do conhecimento? Vale lembrar que, quando interrogamos se existe ou não um 'eu' ou um 'nós' por trás de suas ações/ construções, não estamos tentando eliminar ou apagar o sujeito; mas apenas interrogar as condições em que é produzido e sob as quais opera. Sabemos que a forma como o sujeito é reiterativamente interpelado pelas instituições e autoridades determina, delimita, e alicerça aquilo que é considerado 'humano'. Entretanto, cabe ressaltar que o 'humano' jamais é produzido em contraposição ao que não é humano, mas sim pelas exclusões e pelos apagamentos - ou seja, a partir de tudo o que não é articulado culturalmente ou, como diria Derrida, através do excesso ou de tudo aquilo que ex-orbita os discursos hegemonicamente instituídos. Em outras palavras, tudo aquilo que é excluído e culturalmente ininteligível é o que 'delimita' o humano, e, ao mesmo tempo, assombra-o com a constante possibilidade de ruptura e rearticulação.'

Hoje em dia, a arte e a literatura não apenas não estão alheias a esses questionamentos, como muitos deles nasceram e são elaborados no próprio fazer literário. Mediante o questionamento das noções tradicionais da representação em si e suas possibilidades e a partir do momento em que a 'natureza' e o 'ser' não mais se colocam em estado 'puro' para serem explorados pelo/a artista, e a própria cultura não mais se situa como um agente externo de transformação do 'referente', temos uma literatura, chamada pós-moderna, que tem que lidar com uma 'realidade' e com um 'sujeito' encapsulado por imagens culturais, que tomaram o lugar da 'natureza', ainda existente para boa parte dos modernos. Sem referentes, diante de variações, em vez de fixidez, resta à literatura, mimética por natureza e princípio, a representação de representações de representações (mis-en-abysme), em um desencadeamento infinito de espelhos, cada vez mais dissociados do 'real'.

Assim, desiludida com o referente, a literatura desce do pedestal das Belle Letres, e encurta a distância entre a 'alta cultura' e a 'cultura de massa'. Temas antes considerados 'inapropriados' para a literatura passam a fazer parte de seu organismo pulsante, dando margem a uma imensa diversidade de estilos pessoais, que implodem os próprios conceitos de gêneros literários.

E é nesse contexto conturbado, incerto, polêmico, controverso, que se insere a obra de Arriéte Vilela.

Arriéte, escritora alagoana, de Marechal Deodoro, em sua obra transita exatamente pelos espaços ex-orbitantes, ex-cêntricos; pelos espaços do passado re-visitado, do presente que se the escorrega, nos veios da fantasia, irrecuperável e indizível, no entanto, teimosamente laborado pela palavra.

Nesse mesmo contexto, de uma literatura que se recusa rótulos, de um texto que encontra sua lógica dentro de sua própria ilogicidade, é que se insere a primeira coletânea de ensaios críticos acerca da obra de Arriéte, bravamente organizada pela professora Izabel Brandão.

O livro intitulado Entre o amor e a palavra: olhares sobre Arriéte Vilela reúne trabalhos de professores/as e alunos/as da pós-graduação em Letras da UFAL, que, como sugere o próprio título, oferecem múltiplas perspectivas e possibilidades de 
leitura do texto de Arriéte, que vão desde análises de cunho marxista e sociológico a abordagens psicanalíticas, fenomenológicas, que buscam na fortuna teórica/crítica/mitológica das culturas ocidentais e orientais elementos para melhor entender, 'elucidar', iluminar, enfim, ler o texto de Arriéte.

Entre as questões colocadas nos vários ensaios, chamou a minha atenção a problemática da 'escritura e da autoria feminina', trabalhadas nos textos de lzabel Brandão e de Jerzuí Tomaz, por se tratar de uma questão extremamente complexa e, diria, até arriscada de se abordar. Muito se fala de o texto de Arriéte, sobretudo Fantasia e avesso, ser 'transgressor', como o faz muito bem Edilma Bomfim; muito se fala também dos embates entre a 'autora' e a linguagem, como o faz de maneira perspicaz Roberto Sarmento.

Percebe-se claramente, no texto de Arriéte, o dilema entre linguagem-instrumento e linguagementrave; 'autora'-mulher e linguagem patriarcal.

Assim, acredito que falar de uma 'escritura feminina' é imensamente útil e pertinente, quando se sabe que os valores em que se baseiam os padrões de qualidade literária têm sido predominantemente masculinos, e que as próprias teorias narrativas estão enraizadas na leitura de textos escritos por homens. Portanto, é fundamental uma intervenção sob o viés de gênero. Contudo, temo que o construto 'escritura feminina' pode se constituir em um risco, quando sugere que 'mulher escritora' é uma categoria monolítica, que pode ser representada de forma homogênea. A realidade nos mostra que a categoria 'mulher' é múltipla, diversa, heterogênea; assim sendo, o mesmo pode ser dito a respeito da categoria 'mulher escritora'. O perigo é que uma visão homogeneizante apague as diferenças e as especificidades locais e culturais de raça, etnia, classe social, orientação sexual.

Obviamente, toda discussão acerca da especificidade da 'escritura feminina', seja pelo viés da psicanálise - um discurso falogocêntrico, vale lembrar, como o faz Jerzuí Tomaz -, seja por qualquer outro viés, é mais que válida, visto que essas questões estão longe de ser esgotadas.

Para finalizar, queria destacar a argúcia com que Izabel Brandão, em seu ensaio "Fantasia e avesso: entre papoulas, mel e máscaras", trata da questão do amor em Fantasia e avesso, como uma quase re-escritura d'O Banquete, de Platão. Izabel Brandão parece-me ser a única, até então, a dizer de fato a que diz respeito o "amor clandestino" de Fantasia e avesso, quando afirma que o livro "rompe com o amor-norma que permeia a sociedade ocidental e exalta-se/esbalda-se na proposta do amor entre iguais do sexo feminino" (p. 71).

Mas, apesar de o eu-narrador ser potencialmente feminino, o amado é gendrado no masculino, lembra-nos Izabel. Eu acrescentaria que a incerteza, em si, com relação aos gêneros do/a amante e do amado/a que se segue, e que tem marcado as mais diversas análises do livro, revela a sua maior fortaleza enquanto narrativa, se entendermos por narrativa "qualquer discurso que se mobiliza pelo desejo de construir uma história, um relato dos limites e das fronteiras de gênero, subjetividade e conhecimento". ${ }^{2}$ As possíveis identidades de gênero são construídas e desconstruídas no desenrolar do próprio fio narrativo, e assim cria-se uma ambigüidade de gênero que inaugura novos espaços discursivos, onde se inscreve o 'outro', o 'ex-cêntrico'. Exatamente porque é no espaço da narrativa que a 'mulher escritora' pode negociar a contradição entre uma identidade naturalizada e identidades múltiplas, contingentes, bordadas no avesso do discurso patriarcal. Portanto, é através da narrativa que se pode fraturar e reverter - processo, que chamaria de 'aculturação identitária'.

Assim, dentro de um momento histórico, inevitavelmente, e, fundamentalmente, contraditório, repleto de incertezas e interrogações, gostaria de ressaltar a dupla importância dessa coletânea organizada por Izabel Brandão: primeiro, como uma produção acadêmica séria, corajosa, comprometida, rica nas suas múltiplas abordagens; segundo e, acima de tudo, como um estudo crítico sobre uma escritora alagoana, contemporânea, viva. Fato raríssimo na história da crítica literária, sobretudo, na história de um país e de um estado nos quais é tão difícil produzir conhecimento.

1 BUTLER, Judith. Bodies that Matter: On the Discursive Limits of "Sex". New York: Routledge, 1993. p. 7-9.

${ }^{2}$ ROBINSON, Sally. Engendering the Subject: Gender and SelfRepresentation in Contemporary Women's Fiction. Albany: SUNY Press, 1991. p. 17.
ANA CECÍLIA ACIOLI LIMA

Universidade Federal de Alagoas 


\section{Novas tecnologias reprodutivas: uma oferta de possibilidades contraditórias para as mulheres}

\begin{abstract}
New Reproductive Technologies, Women's Health and Autonomy: Freedom or Dependency?
\end{abstract}

GUPTA, Jyostna Agnihotri.

New Delhi: Sage Publications, 2000. 625 p.

O livro de Jyostna Gupta retrata o pensamento de uma pesquisadora desconfiada do processo de medicalização da reprodução humana: é, sobretudo, uma proposta de debate sobre a extensão do impacto das novas tecnologias reprodutivas na sociedade. Aproveitando-se de sua duplicidade cultural - a autora é indiana por acaso e holandesa por opção -, Jyostna Gupta procurou dar vida às suas idéias escolhendo como cenários de levantamento de dados para sua pesquisa a Índia e a Holanda. Ela acredita ser impossível avaliar o impacto das novas tecnologias reprodutivas descontextualizando-as das realidades onde são colocadas em prática. Jyostna Gupta busca desvendar qual é a contribuição efetiva das novas tecnologias reprodutivas ao processo de emancipação e autonomia das mulheres, questionando, ao mesmo tempo, em que medida a persecução de tal objetivo significa abdicar de uma certa dose de liberdade.

As novas tecnologias reprodutivas são um mosaico de desafios visivelmente distintos - o que é, inexoravelmente, sedutor. Ciente do limbo moral e cultural a respeito do assunto, Jyostna Gupta lançouse na pesquisa valendo-se do princípio da autonomia como ferramenta-base de trabalho. O princípio ético da autonomia é um dos eixos fundamentais das teorias bioéticas e de grande parte das teorias feministas. A escritora, por sua vez, permanece em um dos extremos da linha de oscilação das correntes teóricas de estudos feministas sobre as novas tecnologias reprodutivas, adotando uma postura mais resistente à medicina reprodutiva. Jyostna Gupta declara sua posição de forma enfática: "...as tecnologias reprodutivas significam meios de controle da sexualidade da mulher, na redução do corpo feminino como mera entidade biológica..." (p. 593).

Quando declara sua desconfiança, a pesquisadora se justifica afirmando que, por trás das campanhas de difusão das técnicas de reprodução humana por meio do apoio médico-laboratorial, existe um viés sexista, racista e eugênico - muitas vezes não explícito. Jyostna Gupta não explica o porquê, mas não aceita a eugenia. A pesquisadora limita-se a conceituar o termo, na visão dualista da eugenia positiva e negativa. A obra de Jyostna Gupta é repleta de uma abordagem histórica - favorável ao leitor leigo -, o que revela a crença da autora na idéia de que a proliferação da medicalização da reprodução humana é um processo de retroalimentação em constante expansão.

Jyostna Gupta aponta o intercâmbio entre os três significados da maternidade como o pontochave de desconstrução e reconstrução da ideologia da maternidade: para ela, os elementos biológico, social e simbólico interagem, de modo que a mudança de um pode influenciar os demais, levando a uma nova perspectiva acerca da ideologia da maternidade. O próprio desenvolvimento das novas tecnologias reprodutivas levou à "...desconstrução da maternidade como um processo biológico unificado..." (p. 114): a inseminação heteróloga por meio da maternidade de substituição, correlato formal de barriga de aluguel, é exemplo da dissociação entre parentalidade feminina biológica e social. Para a autora, a introdução e a difusão das tecnologias reprodutivas no cotidiano da comunidade mundial significam novos modelos de maternidade 'responsável', reforçando a indivisibilidade da parentalidade, quando à mulher é repassada toda a carga de responsabilidade sobre a prole.

Em conseqüência das novas tecnologias reprodutivas, a pesquisadora Jyostna Gupta propõe um debate sobre a utilização da tecnologia genética na reprodução tanto na Índia quanto na Holanda, explicitando o abismo que separa as duas nações na exploração dos recursos biotecnológicos. De fato, o que parecia ser pura ficção, torna-se acessível ao mundo real: o "Admirável Mundo Novo" de Aldous Huxley é, hoje, uma alternativa bastante palpável. Isso significa, no entender da pesquisadora, que o 
alvo principal de algumas políticas não se restringirá apenas ao controle geral da qualidade da população, mas ao controle do núcleo genético dos seres humanos, que tão-somente pode ser feito através de controle social da reprodução humana. E, nesse ponto, Jyostna Gupta convence seu/sua leitor/a: inquestionavelmente, essa hipótese de controle tão-somente pode acontecer se houver intensa participação feminina. Isso significa mais uma forma de controle da mulher.

Ao elaborar a interface entre emancipação feminina e meios de controle de fertilidade humana, a escritora revela a outra face das novas tecnologias reprodutivas, quando a mulher, na busca por um instrumento de independência e emancipação, acaba se tornando refém de suas próprias escolhas. Sob esse ângulo, as novas tecnologias reprodutivas são um processo camuflado de renúncia tácita à autonomia: as mulheres estão cada vez mais dependentes das tecnologias reprodutivas para engravidar e reproduzir, mesmo quando inexiste impedimento natural à concepção. Segundo a escritora, isso significa que a política de apresentação das tecnologias reprodutivas como oferta de último caso, como alternativa para contornar situações específicas, é falaciosa: não há opção, pois há um estímulo à compulsão pelo uso das novas tecnologias reprodutivas. Analisando o texto de Jyostna Gupta, fica possível concluir que as tecnologias reprodutivas são o retrato da dependência feminina - uma contradição.

Os contrastes entre a realidade indiana e o mundo holandês são valiosos para se entender um dos propósitos de Jyostna Gupta ao escrever o livro. Quando a escritora aborda a necessidade de aprimoramento das políicas públicas de controle populacional, em uma chamada à importância dos cuidados à saúde feminina e infantil, ela possibilita que o leitor perceba que, embora a Índia esteja atenta ao avanço das tecnologias reprodutivas, o desvio de incentivos financeiros pró-sociedade no país minam as expectativas de sucesso na redução das taxas de natalidade. O objetivo de Jyostna Gupta é mostrar que, como resultado desse tipo de atitude negligente e ilícita na distribuição das arrecadações orçamentárias, a população feminina continua sendo afrontada no exercício de sua autonomia, pois o verdadeiro propósito das campanhas e políticas públicas - de ajudar as mulheres a aprender controlar por si mesmas sua fertilidade, entre outras coisas - foi abandonado. $O$ que se noticia, surpreendentemente, no decorrer da narrativa, é o estabelecimento de uma política de interesses, em que a esterilização masculina é eleita como método menos trabalhoso para se alcançar os objetivos de controle populacional.

É interessante o alerta da escritora quanto à importância de proteger a cultura e tradições dos povos: Jyostna Gupta chama a atenção para o descaso em relação à destruição da cultura reprodutiva tanto da Holanda quanto da Índia. A proliferação das novas tecnologias reprodutivas incentiva em larga escala a desvalorização e o conseqüente abandono de heranças antigas. A balança está desequilibrada: 0 abuso e $\circ$ uso indiscriminado das possibilidades oferecidas pelas novas técnicas têm sufocado as demais alternativas não-medicalizadas de procriação humana. Em razão dessa sacralização da ciência, o costume holandês de intervenção da parteira na gestação foi substituído aos poucos pelo exclusivo trabalho dos especialistas, retirando da mulher mais uma ferramenta de independência feminina. Por outro lado, a autora revela, na Índia, um processo similar, em que as tradicionais auxiliares de partos foram trocadas pela higiene e pelo conhecimento especializado dos processos físicos de reprodução disponíveis nas clínicas de tecnologias reprodutivas. Episódios como esses revelam o quanto a mulher é subestimada como agente capaz de aprender: na verdade, o que fica transparente é o contínuo desejo de sufocar as mínimas demonstrações de exercício de autonomia pelas mulheres.

Existe um aspecto interessante na pesquisa de Jyostna Gupta. Quando a pesquisadora elegeu a autonomia como princípio norteador para solucionar suas questões, criou, de imediato, uma atmosfera de conflitos, porque, na mesma medida, a autonomia também representou um obstáculo às suas conclusões. No caso da possibilidade de predeterminação sexual dos fetos, é curioso como Jyostna Gupta segue a mesma direção das demais feministas: apesar de estar ciente da preferência pelo sexo masculino nas famílias indianas, ela não diz em momento algum de seu texto que tal intervenção é errada, exatamente porque tal assertiva significaria uma afronta à soberania do princípio da autonomia em si. Nesse exato ponto, a escritora opta apenas em alertar que a oferta de mais opções de escolha não necessariamente significa ou conduz a mais autonomia para as mulheres. Assim, Jyostna Gupta prefere assumir o risco de que a sociedade irá se auto-regulamentar quanto à utilização da préseleção sexual a defender a intromissão no exercício pleno da autonomia reprodutiva, fruto de árdua conquista. Sem dúvida, é mesmo um ônus grave 
permitir a intervenção direta na autonomia, mesmo que seja em relação à possibilidade de predeterminação sexual dos futuros filhos.

Em geral, percebe-se nos escritos de bioética feminista a presença velada de um temor diante da potencialidade do exercício pleno da liberdade reprodutiva em camuflar ideais sexistas. Nesse contexto, as pesquisadoras feministas enfrentam o dilema da vulnerabilidade de suas proposições em nome da hegemonia do princípio da autonomia reprodutiva. A utilização do princípio como ferramenta de defesa na justificativa para concretização de um processo de predeterminação do sexo fetal forma a estrutura de um paradoxo para a bioética feminista. É este o grande dilema da discussão: apesar de a autonomia ser o emblema das teorias feministas pela emancipação da mulher na sociedade, o princípio, encarado sem restrições, permite a utilização da pré-seleção sexual nos fetos, o que, em geral, leva à interrupção voluntária das gestações daqueles fetos de sexo feminino, não obstante a perfeita condição física e neurológica do feto em desenvolvimento.

Porém, quando Jyostna Gupta deixa de incorporar um conjunto de dados fruto de sua fórmula mista de pesquisa - foram realizadas entrevistas com grupos e indivíduos abrangendo usuários, nãousuários, potenciais usuários das novas tecnologias reprodutivas, além de legisladores, representantes de organismos internacionais ativistas, entre outros a pesquisadora frustra a expectativa do/a leitor/a, que busca, sobretudo, burlar as dificuldades de se compor um universo etnográfico sobre o assunto. Apesar de enfatizar, em alguma medida, que tanto a Holanda quanto a Índia continuam sob o domínio de tradições em que o segredo e o estigma sobre as implicações das novas tecnologias reprodutivas imperam, cada um nos limites de suas singularidades, Jyostna Gupta não aproveita a ocasião para desvelar a realidade: a pesquisadora simplesmente se abstém de fornecer ao/à leitor/a as valiosas informações coletadas em suas dinâmicas de trabalho, provocando um descompasso entre o conteúdo de sua obra e o título em si. No Brasil, por exemplo, onde há uma carência de relatos etnográficos sobre as mulheres usuárias da medicina reprodutiva, se Jyostna Gupta tivesse optado por uma estratégia diferente, em que traçasse um paralelo crítico entre os resultados de suas entrevistas e dinâmicas de grupo e suas disposições, sua obra seria fonte potencial de discussão, podendo tornarse um paradigma para um ambiente repleto de lacunas e dúvidas.

Jyostna Gupta foi prolixa, provavelmente em razão de seu estilo indiano de escrita. O livro traz no seu cerne uma desconexão de capítulos desfavorável à compreensão de suas idéias: a cada novo capítulo o leitor se depara com uma espécie de 'sublivro'. Essa circularidade acabou trazendo um resultado final de pouca profundidade ao conteúdo do texto. Mas, por outro lado, o mérito da pesquisadora está exatamente no grau acessivel da obra: a escritora elaborou um manual de compilação que traz um excelente levantamento bibliográfico, abordando de tudo um pouco, propiciando ao/à pesquisador/a iniciante o acesso a um panorama histórico, teórico, conceitual e ideológico do assunto. A obra de Jyostna Gupta é um marco social e acadêmico: reacende os debates sobre os alcances das novas tecnologias reprodutivas.

Arryanne Queiroz

ANIS - Instituto de Bioética, Direitos Humanos e Gênero

\section{Narrativas: uma trama etnográfica mais sensível}

\section{Uma trajetória em narrativas}

KOFES, Suely.

Campinas: Mercado de Letras, 2001. 192 p

O livro Uma trajetória em narrativas tem a virtude da narradora (no sentido benjaminiano da palavra), que vai a Goiás Velho procurar nos becos da memória alguém que foi esquecida e que reaparece alhures sob a forma de uma bruxa, reclusa no tempo e no espaço.

Meu primeiro contato com a história de Consuelo Caiado não foi sólido como o que agora tenho nas mãos, mas permaneceu denso e impactante, não só para mim mas também para a platéia heterogênea que atentamente ouvia Suely Kofes e imaginava a personagem, seus enredos e seus múltiplos significados.

O fio condutor do livro é a história de Consuelo Caiado, uma mulher que ocupou a cena pública 
na antiga capital de Goiás e que foi esquecida, tornando-se uma 'lembrança privada' nas conversas, pelo menos até a chegada da autora do livro na cidade.

Kofes encontra o fio da meada em Campinas (SP), quando escuta uma narrativa quase mítica sobre uma renunciante, auto-reclusa. Ao longo do livro ela nos conduz através de relatos, monumentos, anotações, relatórios, resistências, descrições, jornais, enfim, de um trabalho arqueológico dos saberes, fazeres, do tempo e do 'clima' da época. Representações que retratam o contexto da existência de Consuelo Caiado pré e pós- reclusão. Surge então a história de uma menina, nascida de uma família tradicional de Goiás, fruto também de um matrimônio entre dois mundos: o rural oligárquico, áspero, distante, de um coronelismo agreste, onde imperava seu pai; ' e o mundo polido, civilizado, requintado, aristocrático, que gerou sua mãe no final do século XIX. A mãe sucumbe às agruras do sertão e Consuelo, e duas irmãs são criadas no ambiente de seus avós maternos, recebendo a primeira formação em colégios franceses do Rio de Janeiro. Na adolescência, ela retorna ao mundo rural de seu pai e madrasta na adolescência, onde fará sua formação profissional como farmacêutica e construirá uma trajetória de atuação feminista, científica e memorialística, marcando também presença social e política a ponto de ser apontada como a 'Totó Caiado de saias'. ${ }^{2}$

A partir daí a autora narra a trajetória de vida de uma mulher sui generis que deixou vestígios de comportamentos e atitudes surpreendentes, fatos que vão sendo desvelados e compreendidos pela trama paralela do trabalho investigativo da pesquisadora.

Kofes abre o texto descrevendo os personagens que atuarão na trama e seu cenário, mostrando ainda as questões que ordenaram o trabalho, seus pressupostos orientadores, apresentando os autores com quem dialoga. Busca inspiração em uma abordagem, se posso dizer assim, etno-biográfica, como por exemplo os trabalhos de Herbert Baldus e Darci Ribeiro. ${ }^{3}$ Ao longo do texto pontua também as questões relativas ao gênero relevadas "na tentativa de compreender a trajetória de Consuelo e ordenar o que seria sua experiência" (p. 15). Kofes dialoga no decorrer do livro com autores do campo da antropologia, como Claude LéviStrauss, Pierre Bourdieu, entre outros, e, no que diz respeito a gênero, principalmente com Marilyn Strathern. Traz também para o seu texto contribuições da literatura, da história, da sociologia e, no que tange à teoria sobre narrativas, basicamente dialoga com Paul Ricoeur.

A autora recusa o rótulo de "biógrafa de uma mulher excepcional", afirmando que

Nem é biografia, nem compartilho o pressuposto de trajetórias excepcionais, nem considero 'mulher' uma identidade fixa. Aliás, no caso, é exatamente na ambigüidade de uma 'identidade de gênero' onde situo a experiência de Consuelo (p. 15-16).

No primeiro capítulo, intitulado "Itinerário, em busca de uma trajetória", a autora descreve e discute os instrumentos teóricos que lhe permitirão buscar "uma interconexão de temporalidades" em um "agora" e uma "inter-conexão de lugares" em um "aqui" (p. 19) no tempo do trabalho antropológico. Nesse capítulo, Kofes busca compreender os significados da reclusão de Consuelo, compondo uma trajetória esboçada através do que ouviu, viu e leu, assim como as perdas e transformações contidas nas fontes em si e nos diálogos entre elas. A abordagem biográfica vai conduzindo o leitor, já seduzido pela qualidade do texto, a um clima de mistério, onde as questões sobre a reclusão, o esquecimento, a invisibilidade vão sendo desveladas, ainda que sempre sugerindo a existência de outros véus.

Kofes, em certa medida, torna-se um sujeito na trajetória que busca compreender, tecendo enredos como narradora ao mesmo tempo que desconstrói tramas urdidas por valores e pelo poder da escrita, tanto no campo da memória da cidade de Goiás quanto no campo da própria antropologia.

Explicitando seu ângulo de avaliação, a autora descreve a metodologia de seu trabalho da seguinte maneira:

O foco sobre uma singularidade, no caso uma trajetória, revelou várias relações, permitindo que a pesquisa guardasse na intuição biográfica um procedimento etnográfico: orientada pelas perguntas sobre Consuelo Caiado fui seguindo seus caminhos, e o que ouvi e encontrei foi sobre muitas outras coisas. Trata-se agora de escrever sobre esse encontro, entre um itinerário de pesquisa e a trajetória de um sujeito pesquisado (p.23).

O segundo capítulo, intitulado "Etnografia, em tramas: pessoa, personagem, atos, fatos, lugares e tempos", abre-se com o cenário da morte de Iracema Caiado, mãe de Consuelo, noticiada pelos jornais locais. A partir daí vão se abrindo os cenários que são descritos, incluindo fatos do contexto histórico, geográfico, político, social, econômico e cultural da trajetória de Consuelo. Outra parte desse 
capítulo se concentra em documentos e relatos centrados em Consuelo. Enfatiza principalmente sua formação na Faculdade de Farmácia e a ałuação em três espaços: o Gabinete Literário, espaço cultural eminentemente feminino; o conselho editorial do jornal feminino $O$ Lar; e a associação Sociedade para o Progresso Feminino. É nesses espaços, ou melhor, nas pistas deixadas por eles que Suely Kofes encontra preciosas informações sobre "Consuelo: pessoa e personagem nas tramas" e sobre o contexto que a cercava.

A última parte desse capítulo apresenta relatos que cruzam o esforço de esquecimento, menosprezo e ocultação das marcas de Consuelo na cidade com fatos garimpados pela autora em diferentes relatos, documentos e outros registros como mapas e fotos que localizam o leitor no ambiente da trama. Nessa parte final a autora começa a tecer o fio que alinhava o gênero com a cultura, a política e a memória que esquece Consuelo.

No terceiro capítulo a autora investiga o feminismo na década de 1920 e início dos anos 1930 em Goiás Velho, período em que a atuação de Consuelo foi mais significativa. Através de cartas e artigos do jornal $O$ Lar, a autora apresenta as questões, as representações e os valores de masculinidade e feminilidade evidenciados nas "inscrições objetivadas" (p. 22) e nos relatos orais de pessoas contemporâneas de Consuelo.

O quarto capítulo volta à questão teórica da narrativa, seu emprego, sua importância, seus limites e suas formas. A autora agrupa as narrativas sobre Consuelo em três grupos: a) contos de bruxa; b) ausência de enredo (esquecimento e/ou recusa do relato); e c) histórias sobre Consuelo (longas narrativas que recriam a trajetória da personagem central da trama). Nesse capítulo a autora delineia o contraponto entre duas construções de feminilidade, a partir das memórias de Cora Coralina ${ }^{4}$ e de Consuelo.

No quinto capítulo Kofes constrói uma etnografia onde interpreta e costura todas as informações que obteve. Refaz a trajetória de Consuelo marcando suas características de deslocamento familiar, social, cultural, político e de gênero, pontuando a especificidade de sua experiência de duplos pertencimetos (Rio de janeiro/ Goiás, masculino/feminino: Totó de Saias). Nas palavras da autora, "Este situar dilacerado não poderia qualificar essa experiência como estrangeira? Não é como estranha que falam dela quase todas as narrativas?" (p. 171).

No capítulo final, a autora analisa a herança familiar de Consuelo e as narrativas sobre ela: alguém que foi impedida duplamente de conquistar sua herança política - tanto pela rigorosa fronteira de gênero existente na sua época (exemplarmente demonstrada a partir da análise do jornal $O$ Lar, no capítulo 5) quanto por ter perdido a herança familiar com a morte da mãe. Não se tornou um 'coronel de saias' nem era 'uma flor'; permaneceu representante e prisioneira de um tempo passado, no qual se refugiou.

No que tange ao estilo, inteligente e sensível, o texto é quase literário, com inserções teóricas que Ihe garantem o estatuto de uma tese de livredocência. Sua argúcia e erudição tornam a leitura instigante e profunda. $O$ olhar antropológico da autora desvenda ricos itinerários de pesquisa pouco explorados na antropologia brasileira. Kofes abusa de narrativas longas, obrigando-nos a partilhar do contexto dos relatos, ${ }^{5}$ e a freqüência com que usa esse recurso pode se transformar em um ponto vulnerável de sua bela escritura.

Finalmente, penso que a autora ilumina a natureza relacional e de construção permanente que envolve o gênero na sua articulação com a memória, com a construção da noção de pessoa e com as contingências histórico-político-culturais. Dificilmente, ao conhecer a trajetória de Consuelo Caiado pelas palavras de Kofes, alguém se esquecerá dela.

\footnotetext{
1 Dr. Antônio Caiado, advogado, senador, chefe político regional.

${ }^{2}$ Apelido do pai de Consuelo.

${ }^{3}$ Os trabalhos são, respectivamente, O professor Tiago Marques e o caçador Aipoboreu e Uirá sai à procura de Deus.

${ }^{4}$ A autora insere dados sobre Cora Coralina a fim de comparar duas feminilidades, uma hegemônica, desejada e marcada pela memória, outra estigmatizada e esquecida pela memória social.

${ }^{5}$ Não sem apontar para a importância desses contextos, como demonstra na citação de Hamlet por Bourdieu, p. 2324.
}

BERNADETTE GROSSI DOS SANTOS Universidade do Amazonas 


\section{Fronteiras identitárias e pós-colonialismo}

\section{A voz da crítica canadense no feminino}

HANCIAU, Nubia Jacques et al. (Orgs.).

Rio Grande: Editora da FURG, 2001. 320 p.

No curso da década de 1990, Brasil e Canadá, países até então distantes, aprofundam suas relações cujos caminhos revelam-se, em certa medida, contraditórios: de um lado, pode-se falar no antagonismo comercial, na luta por mercados emergentes, como é caso dos constantes atritos entre a Bombardieu e a Embraer, para ficarmos no terreno da indústria de aviação; de outro, uma constante e profícua aproximação no campo cultural, especialmente a partir da criação, no Brasil, dos Núcleos de Estudos Canadenses, em geral vinculados a Instituições de Ensino Superior; cabe referir, ainda, a organização da Abecan, associação que congrega pesquisadores e professores brasileiros cujo trabalho está centrado nos estudos canadenses.

Em 2001, como resultado precisamente da referida aproximação no plano cultural, foi lançado, pela Editora da Fundação Universidade Federal do Rio Grande, A voz da crítica canadense no feminino, livro organizado pelas pesquisadoras Nubia Jacques Hanciau, Eliane Amaral Campello e Eloína Prati dos Santos, profissionais vinculadas a dois Núcleos de Estudos Canadenses: as duas primeiras, ao sediado na Universidade da Editora; a última, ao localizado na Universidade Federal do Rio Grande do Sul. Tratase de publicação constituída por onze ensaios críticos de autoria de escritoras canadenses, anglófonas e francófonas, em excelentes e criteriosas traduções que estiveram a cargo de especialistas de várias universidades brasileiras.

A publicação, cujo objetivo primeiro foi o de colocar à disposição dos leitores de língua portuguesa material não raras vezes de difícil consulta, vai muito mais além, pois conseguiu estabelecer um belo e instigante painel do pensamento crítico canadense de autoria feminina/ feminista, concebido na contemporaneidade. $O$ texto de abertura, "Vinte páginas entrecortadas de silêncio", de Nicole Brossard, realiza, na forma de um ensaio-depoimento, uma profunda reflexão sobre o lugar e o papel do/a escritor/a em um tempo marcado pela globalização e pelo desenvolvimento do chamado neoliberalismo, época, mais do que nunca, em que as fronteiras identitárias, tal como foram concebidas originalmente no século XIX, correm o risco do desaparecimento. A reflexão dobre a identidade da nação e sobre a identidade do/a escritor/a conduzem a autora à discussão do entrelugar da escritura, como um espaço povoado sempre de múltiplas, ancestrais e contemporâneas vozes, responsáveis pela configuração da literatura como expressão híbrida que se constitui, invariavelmente, na consideração da diferença. $O$ texto de Brossard chega mesmo à postulação do que poderíamos chamar de uma retórica do silêncio, como o lugar de onde o escritor fala em meio à turbulenta polifonia caracterizadora da pósmodernidade.

O segundo texto, "Calçolas do Império: a ilusão do transvestismo", de Diana Brydon, dá continuidade, ainda que por outro viés, à reflexão sobre a questão da identidade, aqui fundamentalmente centrada na questão de gênero, que é igualmente considerada em suas interferências na construção da idéia de nação no Canadá. Brydon, observando sugestão presente em Empire Bloomers, de Margaret Atwood, elege como fio condutor de seu ensaio a idéia de transvestismo, que é investigada em suas manifestações e utilização no campo da literatura, da história e da cultura e em sua repercussão na organização e constituição do Estado canadense. Ensaio fortemente amparado na teoria e na crítica feministas, o texto de Brydon coloca sua ênfase no exame dos estereótipos de gênero a partir dos quais organizou-se a sociedade canadense, no âmbito de um processo colonial europeu, branco e masculino.

O texto de Louise Dupré, que dá seqüência à antologia, debruça-se sobre duas obras de Denise Desautels, que são analisadas a partir do exame do trabalho realizado com a temporalidade, especialmente no que diz respeito à questão da memória: a primeira, obra híbrida do ponto de vista formal, La promeneuse et l'oiseaux, espécie de relato poético que apresenta um eu lírico a pensar sobre si, sua infância e sua própria escritura, é situada no âmbito da poesia do Quebec concebida no curso dos anos 1970; a segunda, Ce fauve, le bonheur, narrativa de cunho autobiográfico que faz correr, paralelamente, dois planos temporais: 0 do percurso da narradora e o da própria história, que é constantemente evocado em suas ocorrências 
significativas para a compreensão da história local e universal. Dupré, valendo-se de teoria de Julia Kristeva sobre o problema da temporalidade, em que se estabelece uma fronteira entre o tempo masculino (linear) e o feminino (cíclico), conclui seu ensaio afirmando ser a obra de Desautels um exemplo de uma visão cíclica do tempo e muito semelhante, senão igual, àquela típica do eu lírico.

"Por uma escrita da resistência: escritoras negras do Canadá", de Bárbara Godard, constitui o quarto ensaio incluído em $A$ voz da crítica canadense no feminino. Nele, a autora discute, entre outras questões, o multiculturalismo, a condição racial e social das escritoras como fatores de inclusão/exclusão no plano das discussões empreendidas pela crítica canadense contemporânea. Registra que, apesar de recente, a teorização feminista começa a incluir, para além da reflexão sobre gênero, os problemas de ordem social e política que envolvem a produção literária de escritoras imigrantes (asiáticas, africanas, latinoamericanas, etc.), normalmente excluídas de qualquer referencial canônico, seja ele de orientação masculina, seja ele de orientação feminista. Formula, então, o desafio a ser enfrentado pela crítica literária, especialmente a de orientação feminista, no sentido de dar conta da diferença, aqui entendida não como uma condição de gênero, mas, sobretudo, como uma questão racial que necessariamente repercute na representação dessas escritoras e, conseqüentemente, de sua identidade no âmbito de suas próprias obras.

A antologia tem seqüência com o ensaio de Mary Jean Green, que aborda a obra de Madeleine Ouellette-Michalska. A autora, a partir de um texto marcado por forte coerência, empreende a leitura da produção de Ouellette-Michalska, que é analisada em seu duplo plano: o ficcional e o teórico. Nesse percurso, Mary Jean focaliza, entre outras obras, La femme de sable, La termitiére, Le plat des lentilles, L'échapée des discours de l'oeil, La tentation de dire e La Maison Trestler, procurando mostrar como a escritora canadense vai, gradativamente, atingindo o estágio de uma inscrição do feminino que havia advogado em seus escritos teóricos. Tal inscrição, segundo a ensaísta, tornou-se possível porque Ouellette-Michalska logra atingir o equilíbrio entre o sujeito feminino e os outros, o corpo e a memória, a ficção e a teoria, o presente e o passado, rompendo com o discurso masculino da história, da autobiografia e do próprio romance.

A análise da narrativa é o motivo dos dois ensaios subseqüentes: o primeiro, de Barbara Havercroft, debruça-se sobre Journal pour Mémoire, de France Théoret, em uma tentativa de desvelamento das estratégias narrativas utilizadas pela romancista em seu relato de feição autobiográfica, no qual se destacam a intertextualidade, a ruptura com a linearidade temporal dos acontecimentos e, sobretudo, a agentividade do discurso, responsável por uma ação transformadora do/a escritor/a e da sociedade; o segundo, de Helen Hoy, focaliza Honour the Sun, da escritora Ojibway Ruby Slipperjack. Em sua análise, Hoy aponta para a necessidade da leitura do silêncio, das lacunas discursivas existentes na narrativa que, organizada em forma de diário, suscita a reflexão sobre a diferença e sobre a função do silêncio (resistência?) no âmbito de uma sociedade multicultural como a canadense.

O oitavo ensaio de $A$ voz da crítica canadense no feminino vem assinado por Nancy Huston, prolífera e premiada romancista canadense. Organizado na forma de um diário, compreendido entre os dias $4 \mathrm{e}$ 19 de julho de 1993, o texto relata visita da escritora ao seu país natal (Canadá), após muitos anos de um auto-exílio que contemplou passagens por $\mathrm{New}$ Hampshire, Boston, Nova York e Paris, cidade onde fixou residência. A viagem, que possibilita o resgate de imagens vinculadas à infância e à adolescência, enseja, em verdade, instigante reflexão sobre a identidade canadense, marcada, no mínimo, pela duplicidade lingüística, responsável, quem sabe, pela ambigüidade que perpassa todas as discussões a respeito da identidade do país.

"O trabalho das mulheres: os irônicos desafios feministas", de Linda Hutcheon, constitui o nono ensaio da antologia. Originalmente capítulo do livro Splitting Images (1991), o texto de Hutcheon, a partir da leitura e análise da obra de escritoras e de artistas plásticas canadenses, procura afirmar a ironia como um tropo retórico utilizado como resistência e crítica à ordem dominante patriarcal. A ironia, nessa perspectiva, seria um meio utilizado pelas mulheres artistas no sentido de subverterem a ordem estabelecida através do investimento na duplicidade do discurso irônico. Além disso, embora focalizando de passagem a questão da identidade canadense, a autora vincula a recorrência ao discurso irônico em obras de artistas canadenses à dualidade identitária do Canadá, em suas múltiplas manifestações.

Lucie Lequin é a autora de "Movimentos da transcultura", texto em que focaliza o papel da literatura produzida no Quebec por escritoras consagradas e por aquelas cujas vozes não encontraram ainda maior ressonância no meio acadêmico ou mesmo junto ao público leitor. Nesse 
percurso, em que investiga a natureza da escrita das mulheres migrantes, lança indagações a respeito das noções de extraterritorialidade, intercultura, desterro, desenraizamento, ambivalência, vistas como categorias indispensáveis para a compreensão e dimensionamento da produção das autoras migrantes. Além disso, pela própria natureza de seu objeto de investigação, a autora não consegue fugir à discussão sobre a questão da identidade dessas autoras, do país e, conseqüentemente, da literatura por elas produzida.

A voz da crítica canadense no feminino se encerra com o texto "O outro romance familiar: filhas e pais na ficção de escritoras quebequenses dos anos 90", de autoria de Lori Saint-Martin. Apoiada na análise de obras de escritoras como Gabrielle Gourdeau, Ying Chen e Monique La Rue, entre outras, a ensaísta aponta para a transformação da literatura quebequense dos anos 1990 no que tange ao tratamento conferido às relações entre pai e filha: se em décadas anteriores, especialmente nas manifestações feministas dos anos 1970, havia a necessidade de exorcizar a figura do pai, nos anos
1990, o tema é redimensionado e dá forma ao que a autora nomeia de "o outro romance familiar".

A leitura de $A$ voz da crítica canadense no feminino revela, de um lado, a variedade de vozes, múltiplas e multifacetadas, que marca o ensaio crítico feminino/feminista canadense na contemporaneidade; de outro, a recorrência a um tema, presente na quase totalidade dos ensaios, que é o debate sobre a questão da identidade, sobretudo naqueles aspectos por ela assumidos em tempos de pós-colonialismo. Mais do que isso, aponta para a ruptura de conceitos ancestralmente aceitos e referendados no âmbito das práticas culturais, em um movimento que, ao recusar o homogêneo, investe no reconhecimento da diferença e da polifonia como marcas definidoras do discurso artístico contemporâneo. Nessa perspectiva, o conjunto de ensaios que integra $A$ voz da crítica canadense no feminino transcende as fronteiras de seu país de origem e contribui para o enriquecimento do debate em torno de questões relevantes para a compreensão da escrita literária na contemporaneidade.

\section{Mulheres e dote no Brasil}

CARLOS ALEXANDRE BAUMGARTEN Fundação Universidade Federal do Rio Grande

\section{O desaparecimento do dote: mulheres, famílias e mudança social em São Paulo, Brasil, 1600 $-1900$}

NAZZARI, Muriel. Tradução de Lólio Lourenço de Oliveira.

São Paulo: Companhia das Letras, 2001. 361

p.

O dote é uma antiga prática, herdada dos portugueses, que inúmeras novelas de época da televisão brasileira já mostraram: o pai, poderoso escravocrata, senhor de engenho de cana-deaçúcar ou fazenda de café, combina o casamento de sua filha com o filho de um outro senhor igualmente poderoso. A moça, chorosa protagonista apaixonada pelo mocinho da trama, levaria consigo um dote, em bens ou dinheiro. Moça sem dote corria o risco de morrer solteira.
José de Alencar, no romance Senhora, foi porta-voz da moça pobre condenada ao celibato forçado, criticando com veemência a prática do dote. Era um 'puxão de orelhas' nos rapazes interesseiros.

Na Inglaterra, o costume do dote durou até o final do século XIX e na Alemanha parece ter persistido até pouco depois da Primeira Guerra Mundial. Na Europa contemporânea já se extinguiu quase completamente, resistindo ainda em pequenas localidades rurais da Grécia, Irlanda, Itália, Espanha, Portugal e Malta. A Índia não o abandonou. Alguns estudos acompanharam o seu declínio em países da América de língua espanhola. ${ }^{1}$

Um livro recentemente traduzido pela editora Companhia das Letras analisa as transformações sofridas por essa prática na longa duração da história de um núcleo urbano específico: a sociedade paulista. Publicado originalmente em 1991, pela Stanford University Press, O desaparecimento do dote foi um longo trabalho de pesquisa, realizado pela professora emérita de história da Indiana University, em inventários dos séculos XVII ao XIX. 
Partindo de uma perspectiva da história econômica, a autora mostra como o declínio dessa prática esteve condicionado às mudanças econômico-sociais sofridas pela sociedade paulista. Conseqüentemente, o casamento, a família e o papel da mulher sofreram profundas modificações ao longo do tempo.

Se no século XVII a mulher de elite era peçachave do sistema produtivo, já que o dote que trazia consigo era a base da viabilização material da família, no século XIX a autora percebeu uma inversão desse papel, pois em um contexto urbano socialmente mais complexo como o paulista, com uma grande maioria de pequenos proprietários, comerciantes e profissionais liberais, os pais não dispunham dos recursos semelhantes aos de seus antepassados para dotar suas filhas, de modo que as moças iam, em boa medida, de mãos abanando para o casamento.

O declínio do dote deslocou a mulher de elite para uma posição secundária no casamento, mas também alterou o próprio sentido do matrimônio, já que passaram a não ser mais os atrativos de enriquecimento que levavam o noivo ao altar. A família extensa e o poder do patriarca, conseqüentemente, foram diminuindo, com a maior necessidade de autonomia dos filhos para se dispersarem em busca do próprio sustento, afinal, não havia mais o aceno de um bom dote, e as transformações econômicas e jurídicas vividas pela sociedade brasileira viriam a debilitar o outrora tão absoluto pater familis.

Antonio Candido, em estudo clássico sobre a família brasileira, ${ }^{2}$ já havia mostrado, em 1972, como se deu a passagem de uma família fortemente patriarcal para a maior independência dos filhos. Sobre o dote, Laima Mesgravis, em 1976, identificou a sua prática por entidades de caridade, como a Santa Casa de Misericórdia de São Paulo, que até 1836 ainda notificava a dotação de uma jovem. ${ }^{3}$ Eni de Mesquita Samara apontou a importância do dote, no século XIX, como estratégia familiar na transmissão do legado. Embora a cidade de São Paulo passasse por transformações econômicas, ocorrendo inclusive um empobrecimento da população, a prática do dote manteve-se, embora readequada aos recursos disponíveis.

Muriel Nazzari, contudo, atenta às conclusões dessas pesquisas, inovou ao documentar, através de uma minuciosa investigação em inventários, esse processo na longa duração dos séculos XVII ao XIX. Para ela, o século XVIII foi a fase de transição, na qual o costume do dote se enfraqueceu bastante, mas ainda era mantido pelas famílias que podiam se dar o luxo de paramentar suas filhas com recursos suficientes para atrair um casamento.
A autora relaciona o declínio do dote na sociedade brasileira, também, ao advento de pressupostos individualizantes, próprios das sociedades modernas burguesas, o que teria levado a uma maior autonomia dos filhos, ao declínio da família patriarcal e ao predomínio do casamento baseado no amor.

Mas essa é uma conclusão bastante questionável, tendo em vista que, em uma sociedade fortemente senhorial e com vigorosa herança personalista e privada, como a brasileira, esses pressupostos individualizantes não parecem ter encontrado ambiente propício para se desenvolverem plenamente, principalmente no século XIX.

A família patriarcal pode ter se enfraquecido na prática, mas em termos das estruturas de pensamento ainda teve vida longa, se é que ainda não tem. Em uma sociedade como a paulista, com o advento da grande lavoura cafeeira, o dote pode ter declinado não pelo avanço do individualismo, mas pelo fortalecimento econômico das famílias cafeeiras, de modo que o casamento pode ter passado a ser um meio de somar fortunas, não de arranjar um genro que tocasse $o$ empreendimento da família da noiva ou a enobrecesse com seu sobrenome.

Temas como casamento e família têm inscrição direta no plano cultural de uma sociedade, de modo que a perspectiva essencialmente econômica da autora a impediu de perceber a especificidade da sociedade brasileira. Mesmo com o declínio da família patriarcal, ainda parece predominar um aroma bem masculino. Mas avançamos, é inegável, embora ainda seja preciso fazer mais. Ao contrário de nossas afortunadas antepassadas, não são nossos pais que decidem sobre nossos maridos, mas continuamos, em boa parte, sendo peça-chave no sustento de nossas famílias. E ai de nós se não trabalharmos para o nosso dote de cada dia...

'LAVRIN, Asunción, and COUTURIER, Edith. "Dowries and Wills: a View of Women's Socioeconomic Role in Colonial Guadalajara and Puebla, 1640-1790". Hispanic American Historical Review 59, n. 2, p. 280-304, 1979. ARROM, Silvia M. "Changes in Mexican Family Law in the Nineteenth Century: the Civil Codes of 1870 and 1884". Journal of Family History 10, n. 3, p. 304-17, autumn 1985.

${ }^{2}$ CANDIDO, Antonio. "The Brazilian Family". In: SMITH, Lynn, and MARCHANT, Alexander. (Orgs.). Brazil: Portrait of Half a Continent. Westport, Conn.: Greenwood Press, 1972.

${ }^{3}$ MESGRAVIS, Laima. A Santa Casa de Misericórdia de São Paulo (1559?-1884). São Paulo: Conselho Estadual de Cultura, 1976.

Denise Aparecida Soares de Moura Universidade de São Paulo 


\section{Mulheres e sustentabilidade na Amazônia}

\section{Mulheres da Floresta Amazônica entre o trabalho e a cultura}

SIMONIAN, Lígia T. C.

Belém: UFPA/NAEA, 2001. 270 p.

Esta nova publicação da antropóloga Lígia Simonian é uma coletânea de artigos escritos em diversos tempos e diversos lugares da Amazônia, resultado de um trabalho de pesquisa de mais de dez anos, retratos do cotidiano de mulheres amazônidas, indígenas e não-indígenas.

É um trabalho que vem contribuir com o debate ambiental sobre desenvolvimento sustentável e/ou sustentabilidade, dirigido principalmente para áreas onde os grupos sociais mantêm tradicionalmente um modo de vida assentado em práticas agroextrativistas. Os debates sobre a sustentabilidade e os modos de viver harmoniosamente com o meio ambiente, principalmente através do enfoque dado pelo ecofeminismo, levantaram a questão do papel das mulheres tanto nesses processos de desenvolvimento quanto no melhor aproveitamento dos recursos naturais. Sobretudo porque se vêem as práticas cotidianas dessas mulheres na perspectiva de uma constante reinvenção de seus conhecimentos acerca desses recursos naturais que se constituem em um saber-fazer que vem, ao longo dos anos, garantindo de certa forma a sobrevivência dos grupos humanos que habitam a Amazônia. Essas práticas, sejam elas referentes a alimentação, a conhecimentos medicinais e sobre cosméticos ou mesmo a reprodução social do grupo, constituem uma cultura não só material mas acima de tudo uma memória histórico-cultural que liga o grupo ao território e lhe conferem uma noção de identidade em relação a outros. São esses aspectos que, para Ligia Simonian, precisam ser levados em consideração nas ações governamentais ou não de desenvolvimento da regiẫo, sob o risco de se perder elementos fundamentais da cultura dessas populações.

Como colocou muito bem Edna Castro em seu Prefácio, a intenção da autora é chamar a atenção para questões relevantes hoje em dia nos debates sobre a Amazônia e os povos que nela vivem. E por ser, talvez, uma coletânea de artigos com diversos enfoques, o que não permite um aprofundamento substancial dos temas, e até mesmo por considerar um conhecimento prévio por parte dos leitores, desenvolve essas questões sem uma explanação detalhada dos conceitos e categorias de análise utilizados, como, para dar um exemplo, o de relações de gênero e empowerment, remetendo sempre que possível o leitor às considerações feitas por outros autores. Por outro lado, acaba por fazer um importante trabalho comparativo e também de divulgação de trabalhos e estudos recentes sobre as mulheres amazônidas, seus saberes e condições de vida, apontando um caminho animador no qual o quadro de silêncio sobre essas mulheres vem mudando gradativamente nos últimos anos.

As mudanças, porém, ainda permanecem no plano teórico, pois quando se trata de exemplos práticos da inserção das mulheres em projetos econômicos e sociais os exemplos escasseiam. Nesse sentido as políticas públicas são exemplos determinantes, ao não integrar as mulheres nos seus questionamentos, decisões e planos para o desenvolvimento (sempre no contexto capitalista), mesmo naqueles em que a sustentabilidade ambiental e socioeconômica é considerada. Aí se concentra todo o esforço da autora em abordar e problematizar essas dificuldades, procurando suas razões para apontar possíveis soluções ao quadro que se apresenta.

Além do persistente silêncio, outra das preocupações da autora é ressaltar que o papel dessas mulheres no desenvolvimento deve ser avaliado de modo crítico, e não somente se restringir a seus aspectos positivos, sob o risco de predominarem as idealizações. Mas ao lermos seus textos ficamos com a impressão de que a luta por inserção das mulheres amazônidas nos processos de desenvolvimento e mesmo de decisões locais das suas comunidades se pauta, em um primeiro momento, por positivar um papel feminino, o qual, por tradição ideológica sexista, vem sendo usado como discurso legitimador de opressão e dominação, qual seja, a 'inerente' ligação mulhernatureza. Esse princípio do ecofeminismo precisa ser tomado com cuidado, pois não basta apenas levar em conta os papéis de gênero atribuídos à mulher. Não é questão apenas de adicionar mais um elemento nas discussões, pois mesmo possíveis 
mudanças nas relações de gênero não significam mudanças concretas no jogo de dominação e opressão. A "revolução cultural" a que se refere a autora só será viável quando o gênero for suprimido, ${ }^{1}$ e não só ele, quando os papéis sociais, sejam eles pautados por sexo, raça ou classe, não mais restringirem as amplas possibilidades de homens $e$ mulheres de interagir na sociedade.

Outro aspecto a ser ressaltado é o uso da categoria 'mulheres'. Por todo o texto a autora procura salientar as diversas experiências históricas e culturais que pluralizam a categoria das 'mulheres'. Reconhecer e pensar as diferenças que as experiências de classe, raça, etnia e sexualidade suscitam acaba por trazer à tona uma questão polêmica acerca da possibilidade ou não da comunhão de experiências de todas as mulheres e assim a produção de um discurso, que englobaria as similaridades entre mulheres de todas as culturas. Procura-se, para isso, valorizar a relação das mulheres com a natureza no sentido de dar certa legitimidade à participação delas nos processos de desenvolvimento, principalmente nos que envolvam sustentabilidade ambiental.

No primeiro artigo a autora discute a relação entre mulheres, gênero e desenvolvimento, atentando para o fato de que são recentes e dispersas as discussões nesse sentido, constatando porém ser indiscutível a existência de avanços nessa relação nos últimos anos. Acompanhando os processos de organização de mulheres principalmente no contexto das reservas e/ou áreas preservadas, Ligia Simonian vai em busca das razões pelas quais as mulheres ainda são preteridas nas decisões tanto no que diz respeito a processos internos de organização de suas comunidades quanto a respeito de projetos e planos de desenvolvimento implementados pelos governos e organizações não-governamentais. Além disso, apenas para citar algumas das questões elencadas pela autora, por que não se enfrenta a questão da violência ou mesmo da prevenção da maternidade precoce? Por que não se prioriza o apoio técnico e financeiro e se oferecem condições para a organização das mulheres em âmbito local, já que constituem mão-de-obra significativa, quando não maioria?

Ela chega à conclusão de que uma solução para esses e outros problemas é "das mais complexas imagináveis" e, "ainda que em sua maioria as mulheres tenham muito de heroínas, nem nessa Amazônia, nem em diferentes partes do mundo, elas, sozinhas, poderão fazer a revolução cultural que o século atual exige. Nessa perspectiva, ainda que tensas, antagônicas ou mesmo violentas, as relações de gênero são fundamentais" (p.62). Apesar dessa menção, a autora utiliza basicamente a categoria 'mulheres', deixando seu conteúdo relacional talvez para uma próxima oportunidade.

O segundo artigo aborda o trabalho das mulheres seringueiras na Amazônia Brasileira, dando ênfase à persistência de uma ideologia sexista que faz com que esse trabalho duro seja encarado como 'trabalho de homem' e assim a atuação das mulheres nessa atividade seja silenciada, fato que contribui para que se formem imagens negativas de mulheres como feiticeiras, mulheres dominadas pelos espíritos da natureza, ou alusões sexistas como 'aquela mulher era o homem da casa'. A autora se utiliza dessa condição social experimentada pelas mulheres seringueiras para chamar a atenção sobre o processo de 'invisibilidade' que encobre o envolvimento de mulheres em atividades culturalmente definidas como masculinas. Discriminação essa que se tem sustentado por muito tempo devido a "circunstâncias históricas e ideologias básicas" (p.98), enfatizando Lígia Simonian que essa visão sobre a divisão sexual do trabalho acabou sendo interiorizada pelas próprias mulheres seringueiras. E para ela é o discurso acadêmico, a documentação produzida e a iconografia que contribuem e devem continuar contribuindo para quebrar o silêncio que envolve $o$ trabalho das mulheres extrativistas.

E se é possível negar ou 'esquecer' a presença de mulheres nas atividades de extração e beneficiamento do látex, o mesmo não se pode fazer com a cultura da castanha. $O$ terceiro artigo aborda a presença incontestável das mulheres nos castanhais do sul do Amapá e seus desdobramentos na memória social dos grupos que vivem nessa regiáo. A lida com a castanha é uma atividade há muito desempenhada pelas mulheres na Amazônia, e essa tradição não deixa negar a importância delas nos processos produtivos envolvendo os castanhais. Importância essa que não se restringe aos aspectos econômicos, pois seus conhecimentos imemoriais constituem-se em um saber-fazer que delineia o social e o cultural de suas comunidades. Saber-fazer que tem influenciado os rumos do desenvolvimento econômico dos extrativistas dessa área, mas que, por si só, não garante às mulheres nem papel decisório, nem recursos destinados a suas atividades pelas políticas públicas. Assim encontramos as mulheres do sul do Amapá às voltas com inúmeros fatores que dificultam seu poder organizativo, um quadro desanimador, mas que só traz mais valor aos movimentos de luta por reconhecimento de sua importância e inserção nos processos de 
desenvolvimento sustentável que estão sendo implementados na região.

$\mathrm{Na}$ esteira desse processo é interessante acompanhar a situação das mulheres indígenas de Roraima, tema do quarto artigo, e seu avanço na tomada de consciência de seu papel nas suas sociedades e principalmente em contextos de política pan-indígena e interétnica. Não há como negar a participação das mulheres indígenas nos embates cotidianos no contexto de aldeia a assim na política, mas elas ainda enfrentam muitos problemas quanto ao exercício e reconhecimento de papéis de liderança. Não é surpresa então constatar o diminuto número de mulheres tomando a frente nas discussões dos processos de organização indígena. Mas, apesar das dificuldades, esse quadro vem mudando, e para caracterizá-lo a autora se propõe a fazer uma discussão sobre a produção teórica em torno da "compreensão sobre o potencial, condições atuais e os limites do processo de organização das mulheres indígenas da área" (p.153).

O infanticídio é tema do último artigo, onde a autora descreve, contextualiza historicamente e analisa essa prática cultural entre as mulheres amundawa e urueu-wau-wau, perfaz uma tentativa de entender as razões de serem as mulheres e não elas e/ou os homens os executores do infanticídio no interior de suas próprias sociedades, e de como cumprem o papel de reprodutoras de uma ideologia mantenedora de tal prática dominantemente na esfera do feminino. Constata que, apesar de algumas mudanças estarem ocorrendo, elas são contraditórias, e considera que não poderia ser diferente, pois as condições psicológicas desses indígenas encontram-se muito deterioradas diante dos efeitos "destrutivos da conquista e dos processos de dominação e de exploração" (p. 238). Além do mais, essa prática está no cerne das discussões sobre especificidades culturais e sobre relações de gênero, problemáticas que emperram os processos de entendimento entre índios e não-índios e que continuam não sendo levadas em consideração pelas políticas e ações do Estado. Esse quadro contribui para a manutenção da dificuldade de acesso dessas mulheres às informações sobre controle de natalidade e/ou práticas anticonceptivas convencionais na sociedade não-índia, ainda mais agora que perderam em parte os conhecimentos ancestrais com relação ao aborto e à concepção, resultado aliás da conquista e convivência com os não-índios.

Enfim, perpassamos várias questões que ligam mulheres, gênero e desenvolvimento, trabalho e recursos naturais, organização política e cultura, mas, como ressalta a própria autora, uma questão teórica unifica as problemáticas abordadas nos diferentes artigos: "a preocupação com o potencial das mulheres num contexto em que, milenarmente, tem dominado a sócio-diversidade". Assim, o livro passeia por esse campo biossocial diversificado que acaba por fundamentar as muitas possibilidades de ser mulher na Amazônia Brasileira.

O que não podemos é ficar apenas na questão da valorização de um papel supostamente feminino, pois mascara a noção de que é um papel que foi construído cultural e historicamente, limitando a proposta de uma verdadeira transformação cultural, pois para isso é preciso levar em conta também os homens. Para uma transformação ser efetiva se faz necessário desconstruir esses papéis dicotômicos de homens e mulheres, para que conjuntamente possam discutir sobre sua sobrevivência e sua relação com o meio ambiente. Deixar de lado esses papéis, papéis pautados no sexo e que naturalizam o 'ser mulher' e o 'ser homem' representando-os como universais, é o que permite a categoria 'gênero'. Assim poderemos analisá-los de modo relacional e historicizá-los de forma a "encontrar seu sentido e como eles funcionavam (nas diferentes sociedades e períodos) para manter a ordem social e para mudá-la". ${ }^{2}$

Para a autora não basta apenas criticar a desconsideração das mulheres e das relações de gênero, mas é preciso, sim, dar ênfase ao que ela chama de "ação participativa", ou seja, dar apoio efetivo às mulheres nas suas ações, já que na prática é preciso levar em consideração que há mulheres e mulheres e muitas contradições em seu meio.

Este livro é muito mais que um livro sobre mulheres; é um compromisso com a valorização de seu papel produtivo, com a luta de inserção de seus interesses e direitos nas decisões das políticas públicas e resistência aos preconceitos que ainda dificultam essa participação. É uma tentativa de quebrar, assim, com a atitude imobilizadora que muitas ainda têm de não crer no seu potencial.

1 RUBIN, Gayle. "The Traffic in Women". In: REITER, Rayna. Towards and Anthropology of Women. New York: Monthly Review Press, 1975.

2 Afirmava assim Natalie Davis, em 1975, citada por SCOT, Joan. "Gênero: uma categoria útil de análise histórica". Educação e Realidade, v. 16, n. 2, p. 5-22, jul./dez. 1990.

KATIUSCIA MARIA LAZARIN

Universidade Federal de Santa Catarina 


\section{A alteridade à flor da pele}

\section{Família, fofoca e honra: etnografia das relações de gênero e violência em grupos populares}

\author{
FONSECA, Cláudia.
}

Porto Alegre: Editora da Universidade/UFRGS, 2000. 245 p.

A autora é uma ótima contadora de histórias, tal como suas interlocutoras das vilas Cachorro Sentado e São João em Porto Alegre. Essa sua engenhosidade acaba por nos presentear com uma leitura envolvente do início ao fim do texto. São seis capítulos que analisam as famílias e suas relações cotidianas; as fofocas; a situação de classe e os pormenores que criam diferença e estranhamento intraclasse; o poder e sua associação com a violência, a honra e o humor; tudo isso ao descortinar seus códigos, suas formas e seus simbolismos espraiados nas dinâmicas de gênero e de classe social. Segue prefácio, sobre a importância do olhar etnográfico; e epílogo, sobre a alteridade na sociedade de classes. Enganar-se-ia quem pensasse que as histórias dos sujeitos falam por si. Elas só ganham sentido pleno quando recuperadas habilmente na sua integridade sociopolítica e interpretadas a partir de um olhar aberto à sua complexidade. Como pesquisadoras e pesquisadores vislumbramos que essa é nossa tarefa, e de fato o é; todavia, normalmente estamos tão informados por 'nossas' teorias que elas viraram autos-de-fé e parcamente de pesquisa. Minha intenção com esse breve preâmbulo é atentar o leitor interessado para as qualidades do texto de Cláudia Fonseca: a captura das lógicas simbólicas dos sujeitos, o desprendimento valorativo e classificatório e, mais importante, a capacidade de explorar outras e possíveis interpretações teóricas, contrapondo, aos modos de ver recorrentes, a análise da complexidade. Os modelos explicativos não são tomados a priori; são antes trabalhados como possibilidades de entendimento. A pesquisadora se debruça sobre os seus dados etnográficos e pensa esses modelos ao apontar suas pertinências, impertinências e limitações na compreensão de comunidades locais.

A beleza do trabalho está na descrição densa sobre a vida de mulheres, homens, jovens, idosos e crianças; na trama de suas existências, em um vaivém de proximidades e distâncias criadas para mostrar suas distinções, suas particularidades e seu destino em comum. A autora recria habilidosamente a concretude das perspectivas dos sujeitos, das sutilezas presentes no cotidiano e dos equilíbrios instáveis e frágeis que regem as relações cotidianas. A análise teórica é tecida, sobretudo, a partir da inflexão sobre a etnografia detalhadamente trabalhada, produzindo conhecimento situado. Assim, os lugares ganham nitidez na imaginação do leitor: a Vila Cachorro Sentado, "rodeada de ruas habitadas pela classe média (...) em torno, muros construídos ou fortificados durante os últimos cinco anos pelos proprietários das ruas circunvizinhas (...) que acreditam assim se proteger da contaminação e dos perigos dos roubos" (p.22); e a Vila São João, com "essas ruas que sobem e descem [em analogia à própria vida dos sujeitos] (...) um emaranhado de trilhas que levam em ziguezague para o território mais pobre do bairro" (p.92-3).

A análise da Vila São João aponta para a vida em sanduíche entre os que têm pouco e os que não têm nada. O cotidiano é recheado de observações jocosas sobre casos particulares. Em especial, os supostos maridos traídos são o alvo predileto das anedotas: "Ah, Leco não te cumprimentou hoje? É que as guampas tão tapando a vista dele!" (p.133). São incontáveis as fofocas pormenorizadas, maldizentes ou bendizentes, conforme o caso, sobre os outros e que fazem a festa no pedaço. Essa 'arma feminina', mas não exclusivamente, abriga a "manipulação da opinião pública" (p.46) e ganha espaço "espalhando boatos (...) para Deus e todo mundo" (p.48), mostrando mulheres astutas, observadoras e hábeis no uso da palavra. Há os enfrentamentos "para fazer-se respeitar", quando importa "provar que não é 'trouxa"'.

"Verdade ou não, as pessoas gostam de contar como, pela malandragem, enrolaram o patrão, 0 psiquiatra, o proprietário da casa ou o juiz" (p.21). A revanche contra situações difíceis, aparentemente inelutáveis para o observador externo, é uma resposta para sobreviver física e subjetivamente aos 
infortúnios de contextos tão adversos, quanto o são a pobreza, a falta de condições nas vilas, o abandono pelas instituições públicas que pouco ou nada se importam com aqueles que mais precisam delas. Apesar disso, os sujeitos que a autora nos apresenta não se dobram, não esmorecem; eles e elas se vingam simbolicamente ao desdenhar de empregados e empregadores. Os primeiros são alvo porque não sabem viver, não têm coragem de ser trabalhadores autônomos ou não conseguem ser proprietários de qualquer coisa, mesmo que seja de um carrinho de papeleiro. Os últimos, os empregadores, embora distantes fisicamente, são tratados ora como burros ora como opressores. Pois bem, os desafetos são enfrentados por meio do desdém, do rebaixamento e, desse modo, infla-se a própria auto-estima, mostra-se aos outros que se é "dono do próprio nariz". Em relação aos "ricos desdenhosos" da Vila São João, por exemplo, querse deixar claro que têm uma moral superior quando não viram as costas aos vizinhos e amigos menos afortunados.

As performances dramáticas dos sujeitos trazem a verve da história oral, encantam a assistência e conjugam informação e formação com pitadas saborosas de imaginação: "Sabe o que eu fiz? Me vesti de velha. Botei um xale, assim, na cabeça (que eu sempre tinha xale, ainda tenho). Botei um vestido bem comprido e fui atrás. Ah! Peguei uma bengala e saí" (p.121). As encenações carregam propósitos tanto de mostrar a coragem, a audácia, a decisão da contadora, quanto de entreter a platéia de vizinhas, parentes e mulheres mais jovens. Ao mesmo tempo, voluntária ou involuntariamente, que se educam os sentidos, são ampliados os horizontes de atuação e enfrentamento.

As inúmeras mulheres valentes que aparecem no texto são, antes de tudo, indignadas com as traições amorosas: "A primeira Ana que encontrei, meti o pé na casa dela e quebrei tudo. (...) Só depois, fui saber que não era ela (...) a amante do meu marido" (p.130). Mesmo que as mulheres não expressem comumente o uso da violência, como o fazem os homens para lustrar e ilustrar sua honra, elas se defendem como podem, usando desde as palavras ferinas até o facão, se for preciso. A valentia e a violência são tão caras aos homens que o preço pode ser a própria vida, e estão, dessa forma, associadas à masculinidade hegemônica. Sua manifestação dá-se por meio de confrontações e acertos de contas diante das humilhações sofridas. As reações violentas têm, na maior parte das vezes, a finalidade de recuperar ou deixar clara sua honra, pois "um homem não faz isso para outro sem estar pronto para morrer" (p.192). Até mesmo os mais fracos, os mais desafortunados, como bem mostra a autora, têm chances de mostrar sua bravura no domínio da proteção da casa.

Poderia, ainda, continuar enumerando os murmúrios, os risos, as dores e as paixões, mas convém deixar às leitoras e aos leitores se deliciarem com sua busca. Todos esses relatos dão vida concreta aos modos de ser e viver de pessoas que olhamos cotidianamente, mas que não vemos porque nos negamos a pensá-las como dignas de estudo para além dos "simulacros de alteridade" (p.224) e da folclorização, por vezes, tão ao gosto da academia, dos agentes sociais e das políticas públicas; todos interessados nos pobres. Sua expressão máxima aparece nos modelos que criam o "hiper-real", o "mais real do que real", nos quais viceja "uma alteridade pré-fabricada", reificando "a beleza do morto" (p.225).

O trabalho de análise da autora é um encontro renovado com a questão de classe social, historicamente um tema caro às esquerdas. $O$ cotidiano das relações e seus arranjos possíveis são o mote para o questionamento teórico, confrontando categorias analíticas. Dentre outras, a contribuição da autora é suspender o reducionismo econômico, que centra sua atenção nas respostas às condições de pobreza - renda e emprego - e que deixa fora da análise os modos de enfrentar as adversidades, a complexidade das relações e a condição de agente dos sujeitos.

A viagem que a autora empreende não é uma odisséia intercontinental para ver o exótico; é um mergulho, logo ali, nas cercanias da cidade. Os questionamentos se dirigem aos pesquisadores que "opuseram tão pouca resistência no que diz respeito à reflexão sobre 'os pobres' de sua própria sociedade" (p.226). O olhar da pesquisadora se volta para sujeitos "demasiadamente próximos de nós" (p.227), não raras vezes, e talvez por isso mesmo, desprestigiados pelos modismos acadêmicos.

MARIE JANE SOARES CARVALHO Universidade Federal do Rio Grande do Sul 


\section{Nacionalidade literária como identidade}

\section{Les rêveries de la femme sauvage}

CIXOUS, Hélène.

Paris: Galilée, 2000. 168 p.

até o dia em que, repentinamente, como se acordasse de um sono de quarenta anos, vi que reconhecia...

Les rêveries de la femme sauvage, de Hélène Cixous, que tem por subtítulo "Cenas primitivas", inscreve-se na esteira do ensaio Photos sans racine, publicado em 1994, no qual a escritora afirma na contracapa: "O que constitui o solo originário, o país natal de minha escritura, é uma vasta extensão de tempo e terras, nos quais se desenrola minha longa e dupla infância. Tenho uma infância com duas memórias". Nesses dois textos Cixous libera uma parte importante da narrativa autobiográfica: sua infância na Argélia. Desde então, a volta à origem constituise em germe de um parto difícil. A feliz liberação se dá pelo fogo sagrado de uma brilhante escritura. Profundamente ligada a cada um dos lugares de onde fugiu, cada instante detestado e detestável constitui-se em figura vital, que Cixous declara não trocar por nenhum doce ou moderado instante no mundo.

Geografia da memória genealógica, Cixous situa Les rêveries de la femme sauvage nas margens da África do Norte. Em sua praia. À esquerda, a oeste, a família paterna, que seguiu o clássico trajeto dos judeus expulsos da Espanha para o Marrocos. Seus avós viajavam no dorso de burros, acompanhando o exército francês como vendedores ambulantes e intérpretes, chegando ao lado ocidental da Argélia, em Oran, cidade natal da escritora, que até hoje guarda características espanholas.

Com a sabedoria que se reconhece em narrativas da maturidade, Cixous entrega-se ao texto e dele extrai a seiva das palavras com o intuito de liberar a paixão, os barulhos antigos, a felicidade inestimável que enfim consegue alcançar: "Eu nunca quis escrever sobre a Argélia, esse país natal desconhecido [...], e ao mesmo tempo observava nesses últimos anos, ao abrir a janela antes do sol nascer, que acontecia de eu ouvir, quer dizer, de acreditar ouvir [...], um latido ao longe, como se fosse a lembrança de um sonho..." (p. 167). Pensado na década de 1990, esse livro zune de barulhos longínquos.

Conduzida pela urgência de dizer e escrever, Cixous inscreve sua voz vibrante, clara e corporal nesse texto cuja palavra caracteriza-se por estar no feminino. Desde 1968 seu nome vem associado às edições des femmes, mulheres que nas décadas de 1970 e 1980 militaram ardentemente em prol da 'diferença sexual'. Figura de proa ao lado de Antoinette Fouque, Luce Irigaray e Julia Kristeva, a grande arte de Cixous é exercida em dois estilos: a ficção e o teatro, destacando-se pelas cenas fortes, nas quais assenta personagens capazes de assombrar a imaginação de quem a lê com a mesma intensidade que povoam a imaginação da própria autora. No teatro, onde a escrita é palavra, ela desdobra sua verve acentuada por uma clara consciência. Ariane Mnouchkine e o seu Théâtre du Soleil abriram-Ihe a via da epopéia, na qual se aplicou em unir o antigo e o atual, o próximo e o longínquo, em atuais entrecruzamentos.

$\mathrm{Na}$ escrita ora enfocada - traçada com rapidez- a obstinada segregação das raças tem gosto de morte. O pai de Cixous, judeu expulso da Espanha, é um médico sem direito ao exercício da profissão; a mãe, judia alemã perseguida por um anti-semitismo agudo, ficou viúva muito cedo; o irmão, o cúmplice de sempre, é freqüentemente associado a uma bicicleta, objeto real e simbólico "ato fundador da morte" -, imaginário que a menininha cobiça em vão. É na cabeça que rodam as imagens do lugar chamado Clos Salembier, na cidade de Argel, "um lugar que logo me agradou intensamente, assim que 0 vi" (p. 66). Imagens intensas, tumultuadas e ruidosas, desfilam em abundância, paralelas à vida difícil da mãe parteira dos árabes, nas favelas.

Ao pintar o próprio retrato na evocação dos próximos, em Les rêveries de la femme sauvage Cixous trabalha o alter ego em espelhamento. No ginásio, a jovem tem a experiência da doença que acomete o corpo social. O espaço da vida quotidiana é fechado por múltiplas portas, tão invisíveis quanto intransponíveis. A brancura da Argélia, justaposta à miséria popular, recebe desde a escola um cheiro de complicação histórica. Muito cedo Hélène transformou-se em combatente de sua própria iniciativa, incapaz de ocultar os enormes obstáculos impostos pela sociedade. Mais tarde ela 
colocará palavras sobre imagens, no momento do estouro do projeto político de Vichy, que articulava o plano de apagamento do ser argelino, o que explica as expulsões súbitas, a incorporação ou a exclusão conhecidas em sua família: "o apagamento do ser judeu".

Como tantas/os outras/os nascidos em Oran, Cixous teve de deixar a terra natal e conquistar uma identidade interior, que chamou de "nacionalidade literária". Única, sua escrita colore-se de uma vida movimentada, que investe retrospectivamente na longínqua memória. Se hoje ela consegue conterse no presente, mostrando e demonstrando-se, do ontem ao agora e vice-versa, nada mais de sua infância parece ordinário. O singular conjuga-se ao universal, explica Cixous, meio feliz, meio infernal, guiada pela força tranqüila das origens, inventando o encadeamento das causas. Não, a infância não se perde no adulto. Todavia, para reencontrar sua força ativa, a escritora evoca um árduo combate, intenso como um filme de terror. Há muito a descobrir nessa Argélia que evoca um país inapreensível e inacessível, tanto para ela que nele habitou quanto para qualquer ocidental. Argel, a intocável. Oran, enterrada nas trevas do esquecimento. Passa-se do terreno pessoal ao histórico por correspondências convincentes, aferindo o impacto da história em todas as dimensões íntimas da vida. Cixous atribui à força argelina de sua imaginação as cicatrizes que marcaram seu corpo. E escreve com brio, ela que pensa o que revê e revê o que hoje os indivíduos empenham-se em esquecer...

Hélène Cixous recebeu vários doutorados honoris causa (Queen's University e Université d'Edmonton, no Canadá, York University, na Inglaterra). Publicou nas Editions des femmes l'heure de Clarice Lispector (1989) e foi contemplada no Brasil com a Ordem do Cruzeiro do Sul pela sua contribuição ao desenvolvimento da literatura brasileira. Participa todos os anos de numerosos encontros internacionais - na Europa, na América e na Ásia - a respeito de sua vasta obra literária e do reconhecido trabalho que empreende em prol dos Estudos Feministas.

NUBIA JACQUES HANCIAU

Fundação Universidade Federal do Rio Grande

\section{Em jogo... os jogos da beleza}

\section{Beleza em jogo: cultura física e comportamento em São Paulo nos anos 20}

SCHPUN, Mônica Raisa.

São Paulo: Boitempo Editorial/Editora SENAC, 1999. $164 \mathrm{p}$.

Os jogos da beleza há muito vêm fazendo parte de nossa cultura, aliás, de muitas culturas. Compostos de estratégias distintas, de valores e múltiplas faces, tais jogos se revestem de diferentes significados: prestígio social, talvez político, ou mesmo como alavanca para uma carreira de sucesso, entre outros tantos. Diferentemente do que possa parecer, os significados dados à beleza não obedecem a qualquer linearidade, tampouco aquilo que pode ser chamado de os "jogos da beleza" surge descolado de um contexto histórico. A beleza, assim como os jogos que a determinam, tem história e como tal está permeada de inúmeras relações, de idas e vindas que se mostram através de pequenos e grandes detalhes: das diferenças visíveis naquilo que chamamos de padrões de beleza aos contextos que os constituem.

Os muitos jogos que envolvem a busca pela beleza têm alcançado nos últimos tempos uma grande notoriedade, que pode ser percebida através de diferentes meios. De capas de revistas que ora se alternam apresentando os segredos da beleza, ora alertam quanto aos problemas que essa busca pode suscitar, aos estudos feitos sobre ambas as perspectivas, percebe-se que um longo caminho tem sido traçado.

Assim, se de um lado têm-se constantemente presente na mídia os mais diversos tipos de debate que envolvem a cultura física, de outro evidencia-se a preocupação de muitos pesquisadores em discutir essa questão. Pesquisas na área de Saúde, Psicologia, Sociologia, Antropologia, entre outras, demonstram e identificam problemas como a bulimia, a anorexia nervosa, entre tantos outros, 0 que tem nos alertado para a emergência do tema. Sob perspectivas muito distintas, esses pesquisadores 
parecem preocupados, sobretudo, com a disseminação de um ideal de beleza magro, jovem e branco.

Por outro lado destaca-se a preocupação em dar historicidade a essa temática, questionando assim quais as relações que estão permeando esse processo que poderíamos definir como o do nosso trato com o corpo. Assim, a história também tem participado desse debate, justamente lembrando a necessidade de contextualizar os padrões, as relações e os contextos que os constituíram e mesmo os sujeitos que são construídos através deles.

Beleza em jogo, de Mônica Raisa Schpun, está entre as contribuições dessa disciplina e como tal nos convida a conhecer, através da análise discursiva, da observação de práticas sociais e de outras atividades, o modo como em determinado período e espaço os padrões de beleza vão sendo construídos e ganhando visibilidade. Apresentado inicialmente como tese de doutorado ò Universidade de Paris VII, com o título de Paulistanos \& Paulistanas: rapports de genre à São Paulo dans le annés vingt, e posteriormente publicado pela Éditions l'harmattarn e pelo Institut des Hautes Études de L'Amérique Latine como Les annés folles à São Paulo, o trabalho de Mônica Schpun aposta portanto em um tema atual, polêmico e instigante.

Em sua análise Schpun observa um contexto e um local específico, a cidade de São Paulo dos anos 1920, investigando como, sob o processo de urbanização dessa cidade, desenharam-se papéis específicos para homens e mulheres a partir de referenciais tidos como próprios aos universos masculino e feminino. A principal implicação de sua problemática é mostrar como o processo de urbanização dessa cidade transformou as relações entre homens e mulheres e como estas, por sua vez, também marcaram as transformações urbanas. $O$ duplo caminho apresentado nessa proposta nos evidencia como os padrões de beleza e mesmo outros valores dados ao corpo são construídos historicamente, como eles emergem em determinados contextos e como também influenciam as próprias relações sociais.

Para nos apresentar sua tese a autora traz um extenso levantamento de fontes que incluem revistas femininas (Cigarra, Revista Feminina), romances, fotografias, reportagens sobre os concursos de beleza e, ainda, os arquivos de clubes de esportes. Nesses espaços, ela mostra como foi criada uma 'pedagogia da beleza', destinada a apresentar padrões, comportamentos e físicos - orientados para uma elite que buscava afirmação de seu prestígio. Isso porque o período em questão marca o processo de reorganização da cidade de São Paulo, onde uma elite cafeeira passava a ocupar o espaço físico e social. Conforme a autora, após a mudança para a cidade, a oligarquia rural passou a pôr em prática estratégias que a distinguissem e que criassem uma identidade dessa classe. Os instrumentos de tal processo de distinção foram expressos, portanto, através dos discursos apresentados nas fontes citadas acima e também através das suas práticas sociais.

Além de recuperar tradições, de investir em figuras heróicas como os bandeirantes, bem como na idéia de modernidade, a elite paulistana recorreu a seus próprios membros para atestar e garantir suas prerrogativas. Para isso, passou então a investir em 'códigos de diferenciação' relativos ao físico, que deveriam ser seguidos nas apresentações públicas.

Mas certamente não seriam as mesmas regras apresentadas a mulheres e homens. Ao contrário, as pedagogias eram diferentes e apostavam em caminhos opostos quanto à apresentação pública feminina e masculina. Assim, homens e mulheres tiveram não apenas prescrições distintas no que diz respeito à sua participação nesse processo de urbanização, mas também passaram por diferentes experiências, como se preocupa em alertar a autora: "o apelo mais freqüente à exibição pública está vinculado à diferença entre os gêneros: a experiência de homens e mulheres é fundamentalmente distinta" (p. 21-22).

E o que significou essa diferenciação? Quais as implicações dessas diferenças? Bem, inicialmente o que se destaca é a oposição entre os parâmetros oferecidos a homens e a mulheres, que podem ser acompanhados desde as práticas esportivas oferecidas a ambos até as vestimentas e a apresentação física propriamente dita.

Segundo a pesquisa de Mônica Schpun, os discursos que remetem às experiências e aos corpos de homens e mulheres estão vinculados a um "imaginário manifestadamente sexuado" (p. 22) e naturalizado, e como tal investem sobre ele. Ou seja, ao se prescrever quais as atividades esportivas, por exemplo, mais apropriadas para cada um dos sexos, o que era aconselhado estava circunscrito ao que se julgava próprio e natural para eles. Essa assimetria nas relações evidencia-se quando descobrimos que tipos de atividades eram aconselhados às mulheres e aos homens, respectivamente: para elas, esportes como dança clássica, natação, ginástica sueca e os exercícios 'menos pesados'; para eles, esportes da força, como atletismo, futebol, lutas, entre outros. Para prescrever atividades esportivas e físicas para os homens e as mulheres foram buscados como parâmetros idéias de preservação do físico e 
aproveitamento dos 'dons naturais', como escreveu a autora: "desde o começo, os discursos que defendem maior atenção à forma física dos jovens, com preocupações higiênicas, eugênicas, médicas, morais ou disciplinares, estabeleceram nítida distinção às práticas aconselhadas a cada sexo, observadas suas diferentes 'naturezas'" (p. 34).

As estratégias discursivas e práticas utilizadas para colocar em ação essas idéias também são destacadas pela autora, através de textos de revistas e de médicos higienistas que se preocupam em listar os benefícios das práticas esportivas. A tônica de tais textos também recai sobre o papel socializador dos esportes, que podem permitir e fortalecer laços de amizade. Mas não é apenas sobre esse fato que a pesquisadora nos chama a atenção. Sem perder seu foco, ela menciona outra fronteira construída entre homens e mulheres ao destacar como a presença feminina nos eventos esportivos é menos sentida que a masculina. Trazendo fotos que atestam a pouca visibilidade das mulheres nos espetáculos públicos desse tipo de sociabilidade, Schpun reforça seu argumento de que a participação feminina estava sendo solicitada de modo restrito, ou melhor, distinto.

Outro ponto que merece destaque na pesquisa dessa historiadora é a análise dos artigos de revistas e outros pronunciamentos que falam especificamente às mulheres sobre beleza, moda, saúde e comércio. Nesses textos, de forma geral o que se pode notar é a instalação da idéia de investimento sobre a beleza e a exibição pública, entretanto esse era um procedimento que deveria ser orientado para evitar excessos na maquiagem, nas roupas, etc. Os discursos médicos, por exemplo, consideravam hábitos importantes a prática de exercícios, uma boa alimentação e os cuidados com a pele, cabelos, unhas, etc., pois isso estava associado à idéia de saúde e juventude, que era o referencial de beleza. Mas como foi dito anteriormente, era necessário impor regras para, sobretudo, evitar a vaidade e aquilo que se chamava de exposição mundana.

É interessante observar que o momento abordado neste trabalho também é marcado por fatos como uma maior circulação das mulheres de elite pelas ruas, bem como a sua transformação em consumidoras. Tais acontecimentos repercutem de modo intenso na imprensa dedicada às mulheres $e$ estão em perfeita associação com a estratégia distintiva adotada pela elite paulistana. Entretanto, para se expor era necessário resguardar a imagem da distinção, ou seja, evitar maquiagem exagerada, roupas ou comportamentos semelhantes às mulheres das camadas pobres ou mesmo às chamadas mulheres fatais. A beleza esperada para ser exibida pela elite era, portanto, a beleza natural, apenas realçada com moderação no uso dos cosméticos.

Percebemos que nesse contexto os jogos da beleza atendem às demandas sociais. A beleza representa e significa prestígio social. Fazer-se bela é, assim, antes de mais nada, um investimento social sobre o qual, não se pode esquecer, passam as atribuições de gênero. A mulher bela não era apenas aquela que se mostrava impecável em suas aparições públicas; ela também deveria demonstrar a graça, a descrição, enfim a natureza de seu gênero.

Em nossos dias as experiências de homens e mulheres no que diz respeito ao cuidado com o corpo passam por outras questões, assim como são outras as exigências feitas. A presença das mulheres na sociedade pode ser percebida das mais diversas formas, e seu relacionamento com os homens é outro. Mas ainda convivemos com padrões de beleza, ainda falamos em corpos certos e errados... Apesar de haver a possibilidade da escolha, ainda parecemos presos a esses jogos onde a beleza é supervalorizada. Mas como foi colocado logo no início desta discussão, cada vez mais essa supervalorização tem sido colocada à prova.

Trabalhos como este de Mônica Schpun são um exemplo e talvez seja aqui que Beleza em jogo mais se destaca. Apresentando as estratégias utilizadas para divulgar determinados padrões de beleza, atribuindo-lhes uma historicidade, esta autora contribui para um debate que deve se aprofundar. Desnaturalizar os estereótipos, historicizar os padrões de beleza, lembrar das 'invenções' que cotidianamente estão presentes em nossas relações são compromissos que devemos assumir. Em jogos, em experiências, a beleza é uma questão histórica, faz parte de muitas das nossas vivências, e como tal precisa ser discutida e problematizada. Esse empreendimento não apenas pode desfazer mitos, desconstruir preconceitos, mas também pode oferecer novas possibilidades: a convivência com a diferença é uma delas. O diálogo é recolocado aqui e espera por respostas...

NUCIA ALEXANDRA SILVA DE OLIVEIRA Universidade Federal de Santa Catarina 